\title{
THE EFFECT OF BLEOMYCIN ON SV40 DNA : CHARACTERISTICS OF BLEOMYCIN ACTION WHICH PRODUCES A SINGLE SCISSION IN A SUPERHELICAL FORM OF SV40 DNA
}

\author{
Hamao Umezawa, Hideki Asakura, Kinichiro Oda* and Senit Hori \\ Institute of Microbial Chemistry \\ Kamiosaki 3-14-23, Shinagawa-ku, Tokyo, Japan
}

MAKOTO HORI**

Showa College of Pharmaceutical Sciences

Tsurumaki 5-1-8, Setagaya-ku, Tokyo, Japan

(Received for publication June 18, 1973)

\begin{abstract}
The effect of bleomycin on the molecular integrity of SV40 DNA was determined under various conditions by taking advantage of the fact that a single scission produced in such a superhelical form of DNA could be clearly manifested by analysis of samples with centrifugation in alkaline sucrose gradients. Conditions were found where the reaction velocity, the rate of disappearance of the characteristic form of DNA, depended on the concentration of bleomycin as well as on the reaction time. In contrast to general enzymatic reactions, bleomycin activity was greater at $0^{\circ} \mathrm{C}$ than at $37^{\circ} \mathrm{C}$. The optimum $\mathrm{pH}$ was 9.1 while no activity was observed below pH 6 or above $\mathrm{pH}$ 13. Additional DNA, irrespective of its source, inhibited the reaction, while RNA had no effect. $\mathrm{Cu}^{++}+$ion at $1 \mathrm{~mm}$ almost completely inhibited the reaction while 2-mercaptoethanol at $1 \mathrm{~mm}$ stimulated the reaction by about 20 fold. No sulfhydryl compound was included in our standard assay system. EDTA at $10 \mathrm{~mm}$ showed no effect.
\end{abstract}

Bleomycin treatment produces a scission of DNA strands both in vivo and in vitro ${ }^{1 \sim 8)}$. In this action, bleomycin neither requires the native conformation ${ }^{7)}$ nor a particular base composition of $\mathrm{DNA}^{18)}$. The fragmentation of DNA by bleomycin, which can be enhanced by addition of reducing or oxidizing agents ${ }^{8,9)}$, is accompanied by release of free bases ${ }^{10)}$ and aldehyde functions ${ }^{3)}$. However, the detailed reaction sequence remains to be elucidated. To characterize bleomycin action, it seemed of primary importance to find reaction conditions where the rate of DNA fragmentation could conveniently be followed as a function of time and drug concentration. Use of SV40 DNA as substrate is of major advantage since its native structure is double-stranded, covalently closed-circular and superhelical. It sediments with $53 \mathrm{~S}$ at an alkaline $\mathrm{pH}$, and if a single scission is produced on either strand of the native form, the products sediment with 18S (single-stranded, closed-circular DNA) and 16S (single-stranded, linear DNA) under the same conditions ${ }^{11)}$. Under restricted conditions, 16S and 18S DNA were found to be the major products of bleomycin action because amounts of slower sedimenting DNA fragments or acid soluble material were negligible. Since bleomycin can act efficiently on DNA even at $0^{\circ} \mathrm{C}$, as will be described below, a critical aspect of our assay system was the use of an extremely alkaline $\mathrm{pH}$ to terminate the reaction. With this assay, reaction velocities as a function of bleomycin concentration were determined as was the effect of temperature, $\mathrm{pH}$ and various additives on the bleomycin activity. In the present paper, these results are presented and the probable mechanism of bleomycin action is discussed.

* Institute of Medical Science, Takanawa, Tokyo.

** To whom requests for reprints should be directed. 


\section{Materials and Methods}

Bleomycin $\mathrm{B}_{2}$ (lot 32, copper-free), supplied by Nihon Kayaku Co., Ltd., Tokyo, was dissolved in $0.1 \mathrm{M}$ Tris- $\mathrm{HCl}, \mathrm{pH} 7.5$ (adjusted at $20^{\circ} \mathrm{C}$ ), or in other appropriate buffered solutions (see legends to Figs. 3 and 4), at a concentration of $160 \mu \mathrm{g} / \mathrm{ml}$ and refrigerated until use. An inactive derivative of bleomycin $\mathrm{B}_{2}$, prepared by treating bleomycin $\mathrm{B}_{2}$ with an enzyme from mouse liver was obtained as reported previously ${ }^{12)}$. SV40 DNA, labeled with ${ }^{3} \mathrm{H}$-thymidine, was prepared according to the method of ODA and DULBECCO ${ }^{13}$, modified so that extraction with phenol was omitted. A tRNA preparation from Escherichia coli K12W6 was a kind gift of Dr. SeKIYA of the Institute. DNA from Pseudomonas fluorescens KY4032, prepared according to the method of ToMITA and SUzUKI ${ }^{14)}$, was kindly supplied by Kyowa-Hakko Co., Ltd., Tokyo.

Strand scission of DNA by bleomycin: Reaction mixtures contained in $200 \mu 1 ; 50 \mathrm{~mm}$ Tris- $\mathrm{HCl}$, pH 7.5 (adjusted at $20^{\circ} \mathrm{C}$ ), SV40 DNA labeled with ${ }^{3} \mathrm{H}$-thymidine $\left(4 \times 10^{-3} \mathrm{~A}_{260 \mathrm{~nm}}\right.$ units, $2,300 \mathrm{cpm}$ ), an indicated concentration of bleomycin $\mathrm{B}_{2}$ or its substitute and, where indicated, $\mathrm{CuSO}_{4}$ or 2-mercaptoethanol. The reaction was initiated by addition of bleomycin $(50 \mu l)$ and allowed to proceed at $0^{\circ} \mathrm{C}$ for 30 minutes except where indicated. The reaction was terminated by addition of $10 \mu \mathrm{l}$ of $5 \mathrm{~N} \mathrm{NaOH}$.

Analysis by alkaline sucrose gradient centrifugation: After termination of reaction, the total reaction mixture was gently layered over $4.6 \mathrm{ml}$ of a linear sucrose gradient, $5 \%$ to $20 \%$ in $3 \mathrm{~N}$ $\mathrm{NaOH}-0.5 \mathrm{M} \mathrm{NaCl}-10 \mathrm{~mm}$ EDTA and centrifuged at 38,000 rpm with a Hitachi RPS-40 rotor (av. $12,000 \times g$ ) for 4 hours at $4^{\circ} \mathrm{C}$ in a Hitachi $55 \mathrm{P}$ or $65 \mathrm{P}$ ultracentrifuge. The centrifuged gradients were pumped out from the bottom to the top and divided into $0.37 \mathrm{ml}$ fractions. Each fraction was mixed with $5 \mathrm{ml}$ of cold $5 \%$ TCA solution and left standing for 20 minutes at $0^{\circ} \mathrm{C}$. The acid-insoluble material of a fraction was collected on a Millipore filter disc, washed with 3 changes of $5 \mathrm{ml}$ of cold 5\% TCA, dried, placed with the filter disc in a counting vial containing $6 \mathrm{ml}$ of scintillation solution (5.0 g of PPO, $0.3 \mathrm{~g}$ of dimethyl POPOP and toluene, in 1 liter) and the radioactivity was measured in an Aloka liquid scintillation spectrophotometer (LSC-653).

Fig. 1. Bleomycin action as a function of time: Sedimentation profiles.

Experimental conditions were as described under Methods with the use of $4 \mu \mathrm{g} / \mathrm{ml}$ of bleomycin $B_{2}$. The reaction period was varied as follows: 2 minutes (b), 5 minutes (c), 15 minutes (d), 30 minutes (e) and 60 minutes (f). The control (a) received no bleomycin and was kept for 60 minutes. The reaction temperature was $0^{\circ} \mathrm{C}$. In a separate experiment $(\mathrm{g})$, a reaction mixture received $4 \mu \mathrm{g} / \mathrm{ml}$ of bleomycin $\mathrm{B}_{2}$ immediately after $\mathrm{pH}$ had been raised above 13 by adding $10 \mu \mathrm{l}$ of $5 \mathrm{~N} \mathrm{NaOH}$ and the mixture was kept for about 120 minutes until analysis.

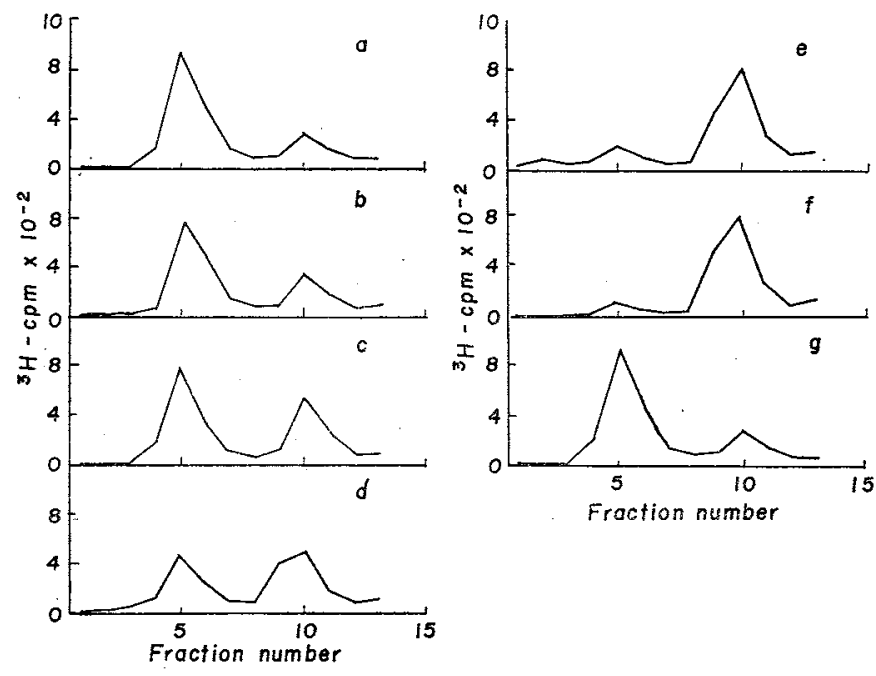




\section{Results}

Bleomycin Action as a Function of Reaction Time

The rate of scission of SV40 DNA caused by bleomycin $B_{2}$ at a concentration of $4 \mu \mathrm{g} / \mathrm{ml}$ was approximately proportional to reaction time up to 30 minutes (Figs. 1 and 2). The experiments were conducted at $0^{\circ} \mathrm{C}$ in the absence of any reducing or oxidizing agent. Since we had already found that bleomycin is active at $0^{\circ} \mathrm{C}$, conditions were first sought where bleomycin activity could be quickly and completely arrested. As shown in Fig. 1-(g), when the pH of the incubation medium was raised to above 13 prior to addition of bleomycin $B_{2}$, the antibiotic did not have an effect at all. Therefore, alkaline $\mathrm{pH}$ was employed to terminate the reaction throughout these studies.

\section{Effect of Hydrogen Ion Concentration on Bleomycin Action}

As shown in Fig. 3, bleomycin activity was dependent on $\mathrm{pH}$; the optimum $\mathrm{pH}$ was 9.1 while no activity was observed below 6 or above 13. The pH-activity curve had 3 distinct maxima.

Fig. 2. Time-course of bleomycin action.

In each of Fig. 1-(a) to Fig. 1-(f), radioactivity in the $53 \mathrm{~S}$ peak and the $16 \sim 18 \mathrm{~S}$ peak, less background counts, was summed up separately and an index expressing bleomycin activity in each run $(R)$ was calculated: $R$ is the ratio of radioactivity in the $16 \sim 18 \mathrm{~S}$ peak to radioactivity in the 53 S peak + radioactivity in the $16 \sim 18$ S peak. In the ordinate in this figure, 0 and 100 represent $R$ of the control run (from Fig. 1-(a)) and the $R$ in the case of total loss of the 53S peak (namely $R=1.0$ ), respectively.

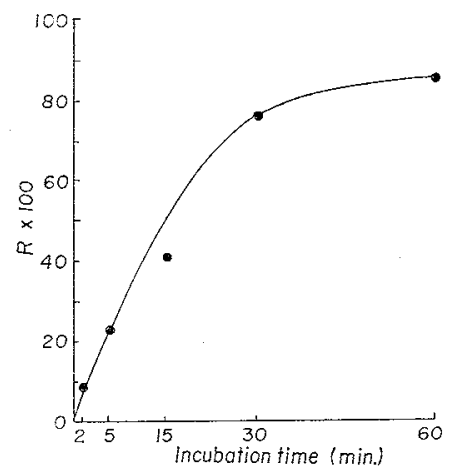

Fig. 3. Effect of hydrogen ion concentrations on bleomycin action.

The reaction mixtures of $\mathrm{pH} 3$ to 8 were based on MCLIVAIN's citric acid-phosphate buffered solution $(0.1 \mathrm{M}$ citric acid- $0.2 \mathrm{M}$ disodium phosphate), while those of $\mathrm{pH} 8.2 \sim 10.8$ were based on ATKINS and PANTIN's sodium carbonate-borate buffered solution $(0.1 \mathrm{~m}$ sodium carbonate- $0.1 \mathrm{M}$ borate potassium chloride). Each reaction mixture $(200 \mu \mathrm{l})$ consisted of $50 \mu \mathrm{l}$ of a buffered solution at the desired $\mathrm{pH}$ (adjusted at $0^{\circ} \mathrm{C}$ with a Hitachi-Horiba pH meter, model F-5), $50 \mu l$ of bleomycin solution (in the same buffered solution), $20 \mu$ l of ${ }^{3} \mathrm{H}-\mathrm{SV} 40 \mathrm{DNA}$ solution (in $1 / 10$ SSC solution-1 mM EDTA, pH 7.0), and $80 \mu 1$ of water. Otherwise, experiments were conducted following standard conditions.

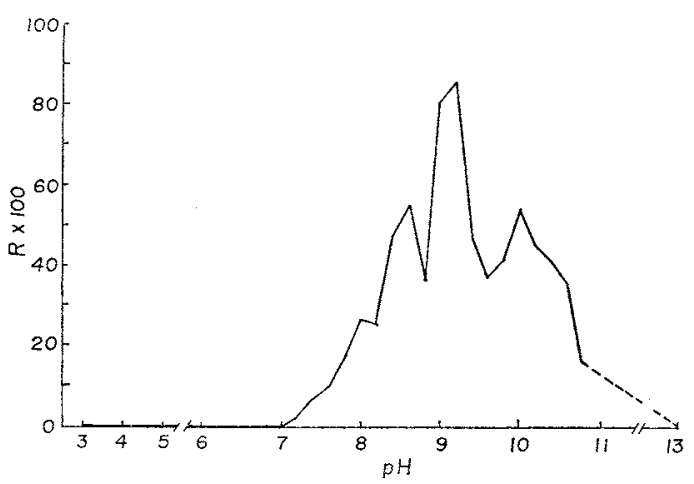

Effect of Temperature

Bleomycin activity is shown as a function of temperature in Fig. 4. The pH of each reaction mixture was adjusted to 9.1 at the respective temperature. It should be noticed that the reaction proceeded more rapidly at $0^{\circ} \mathrm{C}$ than $37^{\circ} \mathrm{C}$. In the range tested, the optimum temperature was $20^{\circ} \mathrm{C}$.

\section{Dependence of Bleomycin Action on its Concentrations}

The effect of bleomycin $\mathbf{B}_{2}$ increased with increasing concentration until a plateau was reached 
Fig. 4. Effect of temperature on bleomycin action. The reaction temperature was varied while the concentration of bleomycin $\mathrm{B}_{2}$ and the reaction period were fixed at $0.5 \mu \mathrm{g} / \mathrm{ml}$ and 30 minutes, respectively. The $\mathrm{pH}$ of reaction mixtures were adjusted to 9.1 (based on ATKINS \& PANTIN's buffered solution, see legend to Fig. 3) at each incubation temperature. Other conditions were as described under Methods. A control run (no bleomycin) was conducted at $37^{\circ} \mathrm{C}$ and its $R$ value (see the legend to Fig. 2) was used for 0 on the ordinate. The sedimentation profile of the control run was essentially identical to Fig. 1-(a).

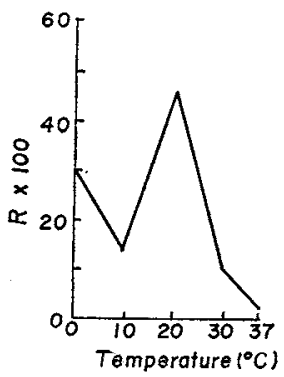

Fig. 5. Dependence of bleomycin action on its concentration.

The effect of bleomycin $\mathrm{B}_{2}$ at concentrations of 0 (control), $0.2,0.4,0.6,1.0,2.0,4.0 *$ and $40 * \mu \mathrm{g} / \mathrm{ml}$ were determined under the standard assay condition where the temperature and the reaction time were fixed at $0^{\circ} \mathrm{C}$ and 30 minutes, respectively. For details, see Methods. Indication of the results are as Fig. 2.

*Conducted as a separate experiment.

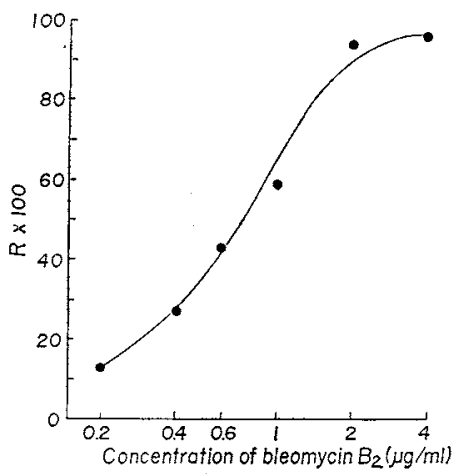

at $2 \mu \mathrm{g} / \mathrm{ml}$, where most DNA molecules were found to have undergone strand scission (Fig. 5). The DNA which had been treated with $2 \mu \mathrm{g} / \mathrm{ml}$ of bleomycin $\mathrm{B}_{2}$ sedimented as a sharp peak in the $16 \sim 18 \mathrm{~S}$ area, while at extremely high concentrations of bleomycin $(40 \mu \mathrm{g} / \mathrm{ml})$ products sedimenting somewhat slower than 16 18S DNA were formed (Fig. 6). However, the radioactivity in the acid soluble fraction under the latter conditions was still negligible.

\section{Effect of DNA Concentrations on Apparent Activity of Bleomycin}

The relative ratio between the concentrations of DNA and bleomycin was critical for the sensitivity of the assay. Upon addition of unlabeled

DNA, either of SV40 itself or of other species, to

Fig. 6. Effect of high concentrations of bleomycin $\mathrm{B}_{2}$ on SV40 DNA.

To obtain a better separation of slower sedimenting products, the centrifugation period was prolonged to 6 hours and the centrifuged solution was divided into $0.28 \mathrm{ml}$ fractions. Otherwise conditions were the same as given in Methods.

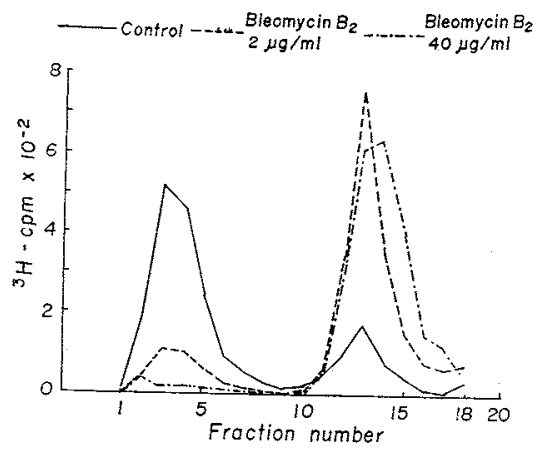

Fig. 7. Effect of DNA or RNA concentration on bleomycin action.

DNA from Pseudomonas fluorescens $\mathrm{KW} 4032$ or tRNA from $E$. coli K $12 W 6$ was added to the reaction mixture at the desired concentration and the reaction was initiated by adding bleomycin $\mathrm{B}_{2}(1 \mu \mathrm{g} / \mathrm{ml})$ and allowed to proceed at $0^{\circ}$ for 30 minutes. Otherwise conditions were the same as given under Methods.

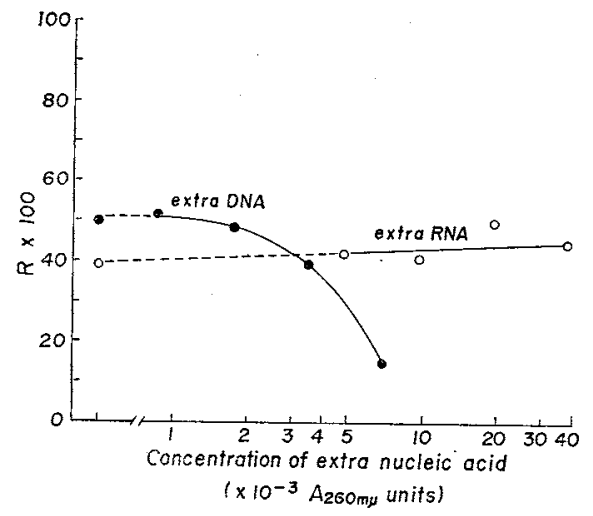


a reaction mixture which contained a fixed amount of ${ }^{8} \mathrm{H}-\mathrm{SV} 40 \mathrm{DNA}$, the apperent effect of bleomycin $\mathrm{B}_{2}$ became less. As shown in Fig. 7, $7 \times 10^{-3} \mathrm{~A}_{280 \mathrm{~nm}}$ units $200 \mu \mathrm{l}$ of DNA from Pseudomonas fluorescens KY4032 almost protected SV40 DNA from bleomycin action. On the contrary, tRNA from $E$. coli K12W6 exerted no effect on the sensitivity of the assay system even at $3.8 \times 10^{-2} \mathrm{~A}_{280 \mathrm{~nm}}$ units $/ 200 \mu \mathrm{l}$ under the same condition.

\section{Other Characteristics}

Bleomycin action, observed under the standard assay condition, was stimulated 20 -fold by $1 \mathrm{~mm}$ 2-mercaptoethanol, since a run with $0.1 \mu \mathrm{g} / \mathrm{ml}$ of bleomycin $\mathrm{B}_{2}$ in combination with $1 \mathrm{~mm} 2$-mercaptoethanol gave a sedimentation profile resembling the one obtained with $2 \mu \mathrm{g} / \mathrm{ml}$ of bleomycin $\mathrm{B}_{2}$ alone. Mercaptoethanol at $1 \mathrm{~mm}$ did not degrade the DNA when incubated with it for as long as 2 hours. Another experiment revealed that $1 \mathrm{mM} \mathrm{CuSO}{ }_{4}$ almost abolished the effect of $1 \mu \mathrm{g} / \mathrm{ml}$ of bleomycin $\mathrm{B}_{2}$. This stimulation and inhibition by 2-mercaptoethanol ${ }^{2,3,4,8)}$ and $\mathrm{CuSO}_{4}{ }^{7)}$, respectively, were as already reported. However, inconsistent with previous reports ${ }^{4,7)}, 10 \mathrm{mM}$ EDTA was without effect on bleomycin action in our assay system. It is known that bleomycin is inactivated in various organs. An enzyme responsible for inactivation of bleomycin was partially purified from mouse liver. A product of bleomycin $\mathrm{B}_{2}$ inactivated by the enzymatic reaction was isolated ${ }^{12}$ and subjected to our assay system. Under conditions where $0.7 \mu \mathrm{g} / \mathrm{ml}$ of bleomycin $\mathrm{B}_{2}$ converted about $50 \%$ of $53 \mathrm{~S}$ DNA to $16 \sim 18 \mathrm{~S} \mathrm{DNA}, 11 \mu \mathrm{g} / \mathrm{ml}$ of the enzymatically inactivated product was required for the same effect.

\section{Discussion}

The preparation of SV40 DNA used in the present study originally included as a minor component the double-stranded, nicked-open-circular DNA (form II), which sediments with S values of 16 and 18 through an alkaline sucrose gradient (Fig. 1-(a)). Bleomycin action also resulted in products sedimenting in the $16 \sim 18 \mathrm{~S}$ region if reaction conditions were restricted to short periods, in the absence of 2-mercatoethanol, and at low concentrations of bleomycin $\mathrm{B}_{2}$ (Fig. 1-(e)). This indicates that we were observing a reaction which produced a single scission in the total molecule of SV40 DNA. For additional strand scission, a much higher concentration of bleomycin $\mathrm{B}_{2}, 40 \mu \mathrm{g} / \mathrm{ml}$, was required. Under these conditions, the DNA fragments sedimented after the $16 \sim 18 \mathrm{~S}$ region (Fig. 6). Suzuki et al. ${ }^{7}$ ) estimated complex formation between ${ }^{3} \mathrm{H}-$ bleomycin $\mathrm{B}_{2}$ and DNA and determined the binding ratio to be one molecule of bleomycin $\mathrm{B}_{2}$ per 350 deoxyribonucleotide residues. In view of the size of SV40 DNA (about 5,000 base pairs, or 10,000 nucleotide residues) and the large excess of bleomycin $\mathrm{B}_{2}$ to DNA in our reaction mixture, for example $6.6 \times 10^{-7} \mathrm{M}(1.0 \mu \mathrm{g} / \mathrm{ml})$ for the former and $3.3 \times 10^{-10} \mathrm{M}$ for the latter, it seems likely that a considerable number of bleomycin $\mathrm{B}_{2}$ molecules bind to one molecule of SV40 DNA. Since only a single scission was produced in a SV40 DNA molecule under restricted conditions, the data suggest that multiple bindings of bleomycin $\mathbf{B}_{2}$ per SV40 molecule lead to conformational distortion which becomes strong enough to produce a strand scission. A nicked-open-circular DNA thus formed, could be rather resistant to another strand scission. The linear time course of bleomycin action (Fig. 2) strongly suggests that bleomycin itself is the active principle capable of producing strand scission in DNA and rules out the mechanism, proposed by NAGAI et al. ${ }^{15)}$, that bleomycin acts only after being activated by some sulfhydryl reagent. In contrast with previous reports ${ }^{4,7)}$, we find that bleomycin action was not inhibited by EDTA. Those previous incubation mixtures contained 2-mercaptoethanol, and it seemed possible that the sulfhydryl reagent was responsible for this inconsistency. We therefore conducted an experiment in which 2-mercaptoethanol was included in the reactson mixture, but still found no inhibition by EDTA. The simplest explanation for the inhibitory effect of EDTA on bleomycin action, which previous authors observed, could be that EDTA removes a trace amount of $\mathrm{Mg}^{++}$ 
which is essential for some contaminating nuclease. Such enzymatic cleavage of DNA may become significant if a mixture is incubated at $37^{\circ} \mathrm{C}$ for a long period.

Bleomycin shows 3 distinct pKá, i.e. $2.9,4.7$ and $7.3^{18)}$. The pKá of 7.3 is due to the amino group* of the moiety below. Since bleomycin activity increased markedly in the $\mathrm{pH}$ range from 7 to 8 , and was negligible below pH 7 (Fig. 3), the unprotonated form of the amino group would appear to be an essential structural component for the bleomycin activity. This view is supported by the fact that when chelated with $\mathrm{Cu}^{++}$, bleomycin lose its ability to cause strand scission of DNA in parallel with

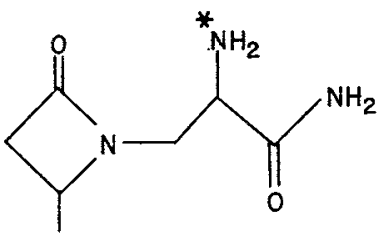
the disappearance of the pKá of 7.3. $\mathrm{Cu}^{++}$-chelated bleomycin $\mathrm{B}_{2}$ (1 atom per molecule) was totally inactive in our assay system. An argument against this mechanism, however, is the fact that for in vivo antibacterial and antitumor activities, $\mathrm{Cu}^{++}{ }_{-}$chelated bleomycins are as active as $\mathrm{Cu}^{++}$-free bleomycins ${ }^{17}$. However, bleomycins chelating $\mathrm{Cu}^{++}$could release $\mathrm{Cu}^{++}$ion in cells and act as the free antibiotics. An enzymatically inactivated derivative of bleomycin $\mathrm{B}_{2}$, which is thought to retain a close resemblance in structure to the parent antibiotic but has slight in vivo activity ${ }^{12}$, was found much less active in producing a scission in DNA. This seems to support the idea that fragmentation of DNA is of primary importance in the in vivo activity of bleomycins.

\section{Acknowledgement}

The authors are grateful to Dr. Marco Rabinovitz, National Institutes of Health, Bethesda, for helpful discussions.

\section{References}

1) SuzukI, H.; K. NaGaI, H. Yamaki, N. TANAKA \& H. UmeZawa: On the mechanism of action of bleomycin: Scission of DNA strands in vitro and in vivo. J. Antibiotics $22: 446 \sim 448,1969$

2) HAidle, C. W.: Fragmentation of DNA by bleomycin. Mol. Pharmacol. 7 : 645 652, 1971

3) MÜller, W.E.G.; Z. YamaZAKI, H. BRETER \& R. K. ZAHN: Action of bleomycin on DNA and RNA. Eur. J. Biochem. $31: 518 \sim 525,1972$

4) Shirakawa, I.; M. Azegami, S. Ishil \& H. Umezawa: Reaction of bleomycin with DNA strand scission of DNA in the absence of sulfhydryl or peroxide compounds. J. Antibiotics $24: 761 \sim 766,1971$

5) Terasima, T.; M. Yasukawa \& H. UmezAwa: Breaks and rejoining of DNA in altered mammalian cells treated with bleomycin. Gann $61: 513 \sim 516,1970$

6) Fujiwara, Y. \& T. Kondo: Strand-scission of Hela cell deoxyribonucleic acid by bleomycin in vitro and in vivo. Biochem. Pharmacol. $22: 323 \sim 333,1973$

7) Suzuki, H.; K. Nagai, E. Akutsu, H. Yamaki, N. Tanaka \& H. Umezawa: On the mechanism of action of bleomycin. Strand scission of DNA caused by bleomycin and its binding to DNA in vitro. J. Antibiotics $23: 473 \sim 480,1970$

8) NAGAI, K.; H. SuzUkI, N. TANAKA \& H. UmEZAWA: Decrease of melting temperature and single strand scission of DNA by bleomycin in the presence of 2-mercaptoethanol. J. Antibiotics $22: 569 \sim 573,1969$

9) NAGAI, K.; H. SuzukI, N. TANAKa \& H. UMEZAwA: Decrease of melting temperature and single strand scission of DNA by bleomycin in the presence of hydrogen peroxide. J. Antibiotics $22: 624 \sim 628,1969$

10) Haidle, C.W.; K. K. Weiss \& M. T. Kuo: Release of free bases from DNA after reaction with bleomycin. Mol. Pharmacol. $8: 531 \sim 537,1972$

11) Vinograd, J.; J. Lebowitz, R. Radloff, R. Watson \& P. Laipis: The twisted circular form of polyoma viral DNA. Proc. Nat. Acad. Sci., U.S. $53: 1104 \sim 1111,1965$

12) Umezawa, H.; T. TAKeuchi, S. Hori, T. SAwa, M. Ishizuka \& T. IChikawa: Studies on the mechanism of antitumor effect of bleomycin on squamous cell carcinoma. J. Antibiotics $25: 409 \sim 420,1972$

13) ODA, K. \& R. Dulbecco: Regulation of transcription of the SV40 DNA in productively infected and in transformed cells. Proc. Nat. Acad. Sci., U.S. $60: 525 \sim 532,1968$

14) TомітA, F. \& T. Suzuki: Extracellular accumulation of DNA by hydrocarbon-utilizing bacteria. Agr. Biol. Chem. $36: 133 \sim 140,1972$ 
15) NAGAI, K.; H. Yamaki, H. Suzuk1, N. TANaka \& H. UmeZawa: The combined effects of bleomycin and sulfhydryl compounds on the thermal denaturation of DNA. Biochem. Biophys. Acta $179: 165 \sim$ 171,1969

16) Takita, T.; Y. Muraoka, T. Yoshioka, A. Fuji, K. Maeda \& H. Umezawa: The chemistry of bleomycin. IX. The structures of bleomycin and phleomycin. J. Antibiotics $25: 755 \sim 758,1972$

17) Umezawa, H.; M. Ishizuka, K. Kimura, J. Iwanaga \& T. Takeuchi: Biological studies on individual bleomycins. J. Antibiotics $21: 592 \sim 602,1968$

18) Haidle, C. W.; M. T. Kuo \& K. K. Weiss: Nucleic acid-Specificity of bleomycin. Biochem. Pharmacol. $21: 3308 \sim 3312,1972$ 